\title{
THE NEXUS OF GOVERNMENT INCENTIVES AND SUSTAINABLE DEVELOPMENT GOALS: IS THE MANAGEMENT OF RESOURCES THE SOLUTION TO NON-PROFIT ORGANISATIONS?
}

\author{
Muhammad ANWAR (D) 1,2, Muhammad Sualeh KHATTAK (iD), \\ József POPP (D) 4,5, Daniel Francois MEYER [D 6 , Domicián MÁTÉ(D)7,8* \\ ${ }^{1}$ College of Economics and Management, Beijing University of Technology, Beijing, China \\ ${ }^{2}$ Witten Institute for Family Business, University of Witten/Herdecke, Witten, Germany \\ ${ }^{3}$ Hamdard Institute of Management Sciences, Islamabad Campus, Pakistan \\ ${ }^{4}$ Faculty of Economics and Social Sciences, Szent István University, H-2100, Gödöllö, Hungary \\ ${ }^{5}$ TRADE Research Entity, North-West University, 1900, Vanderbijlpark, South Africa \\ ${ }^{6}$ TRADE Research Entity, Faculty of Economic and Management Sciences, North-West University, \\ Potchefstroom, South Africa \\ ${ }^{7}$ Department of Engineering Management and Entrepreneurship, Faculty of Engineering, \\ University of Debrecen, $\mathrm{H}-4028$, Debrecen, Hungary \\ ${ }^{8}$ College of Business and Economics, University of Johannesburg, Johannesburg, South Africa
}

Received 11 February 2020; accepted 14 June 2020

\begin{abstract}
Sustainable Development Goals (SDGs) have become the main priority across the globe due to their significant role in economic growth and propensity. However, in particular, it is not yet known how governments can achieve SDGs through non-profit organisations (NPOs) by providing financial and non-financial incentives. The present study included 263 Pakistan NPOs in a primary survey using a questionnaire. The results obtained from the Structural Equation Modelling (SEM) highlight that: (i) government incentives do not directly influence community development; (ii) The government non-financial incentives have a significant direct effect on environmental activities to reduce pollution, energy consumption and waste; (iii) Resource management fully mediates the paths between government incentives and community development while partially mediates environmental activities; and finally, (iv) resource management has a favourable influence both on the goals of community development and environmental activities. This research paper contributes to the knowledge in that government incentives do not have a direct influence on social development, but has an indirect influence through efficient management. Recommendations are that government and public bodies need to support NPOs to engage actively in philanthropic activities. Similarly, NPOs should efficiently utilize and manage the resources to benefit the maximum number of poor and needy individuals.
\end{abstract}

Keywords: community development, environmental activities, emerging economies, government incentives, NPOs, resource management, SDGs.

JEL Classification: L31, M14, Q01, H53.

*Corresponding author. E-mail: mate.domician@eng.unideb.hu 


\section{Introduction}

One of the most important events of 2015 was that the United Nations General Assembly recognized seventeen goals named "Sustainable Development Goals (SDGs)" aiming to end poverty, protect the environment and boost economic growth (Omer \& Noguchi, 2020). SDGs were adopted across the world due to their scope and importance in economic development and social propensity (Scheyvens et al., 2016; Sueyoshi \& Yuan, 2015). During the short period, several studies have shed light on SDGs in advanced and emerging economies (Barua, 2019; Merino-Saum et al., 2018; Nhamo, 2020). In other words, scholars have discussed various determinants such as organizational factors (Rosati \& Faria, 2019), community support (Carius \& Job, 2019), government incentives (Pakdeechoho \& Sukhotu, 2018; Wu \& Si, 2018), regulatory pressure (Cheng et al., 2019), agriculture development (Feliciano, 2019), good governance (Bowen et al., 2017), education sector (Annan-Diab \& Molinari, 2017; Vladimirova \& Le Blanc, 2016), financial resources (Barua, 2019), natural resources (Rasul, 2016), technological resources (Adams et al., 2018; Imaz \& Sheinbaum, 2017) that influence SDGs. Studies have also highlighted the importance of business (Rosati \& Faria, 2019) and non-business organizations (Arhin, 2016; Hassan et al., 2019; Apostolopoulos et al., 2018) in the attainment of SDGs.

Despite the burgeoning literature, implementation and attainment of SDGs are still at an early stage worldwide. In particular, studies have neglected the role of government incentives in SDGs that can be gained via Non-Profit Organizations (NPOs). Moreover, it is not clear whether government incentives (financial and nonfinancial) directly lead NPOs to SDGs, or they first manage the resources efficiently that results in sustainable development. Hence, this research is the first attempt to analyse and highlight the influence of government incentives on SDGs with a mediating role of resource management by NPOs. We used two major SDGs; environmental activities and community support because these goals cover a wide range of activities that are supportive of poor communities and societies. Environmental activities and community supports might decrease and eliminate pressures on the environment and aim at contributing more efficient usage of natural resources (United Nations, 2003). For instance, the investigation in such technologies and consultation actions is designed to prevent or reduce pollution, energy consumption, waste etc., restoring and protecting the economy from a deteriorated environment by recycling, energy conservation and resource management.

There are solid rationalities and goals behind the conduction of this research. The first reason to investigate the government role in SDGs is steered by a lack of research in developing economies. Despite an in-depth search, we were unable to find a study that describes the importance of financial and nonfinancial incentives in the attainment of SDGs, though discussion on government policies and strategies for SDGs exist (Alińska et al., 2018). In particular, the distinct role of government support in SDGs has been neglected. Second, the reason behind targeting NPOs takes us back to the NPOs' functions in emerging markets such as Pakistan. For instance, Anwar et al. (2020) scrutinized that NPOs in Pakistan are engaged in social activities and community support. However, organizations in emerging economies often face resource constraints that hamper their operational and functional activities. This limitation coerces their search for external support and incentives (Songling et al., 2018). 
Additionally, environmental and social activities need adequate financial resources (Memon et al., 2020) and many organizations due to limited financial resources do not participate in volunteer activities (Danso et al., 2019). Hence, we believe that the endeavour is cherished to test if government incentives motivate NPOs toward SDGs. For instance, Lin (2019) claimed that partnership between government and business is vital for better environmental practices, green initiatives and eco-innovation in emerging economies. Favouring the notion, Vasco-Correa et al. (2018) revealed that government incentive is the primary element to reflect and enhance environmental and eco practices in developing and developed economies. The third motive of this research is to assess the mediating role of resource management, which is vital in business and non-business organizations. For instance, Ali et al. (2019) claimed that the management of resources is very crucial for social, environmental and economic performance.

Similarly, Mia et al. (2016) also deliberated that the efficient allocation of resources in poor communities and societies is vital for social and environmental activities. Because it is deliberated that the government of Pakistan tries to provide financial incentives for social organizations, but the managing of these resources is perhaps lacking. Therefore, it is a unique phenomenon to discover if resource management mediates the path between government incentives and SDGs in NPOs.

SDGs are debated in different viewpoints and tested with several theories by scholars and academia. However, this study contributes to the Resource-Based View Theory (RBVT) (Barney, 1991) that has been rarely tested in NPOs. The RBVT sheds light on the worth of tangible and intangible resources that spur the competitive advantage and performance of organizations. In the research, government incentives are deemed valuable resources that can motivate NPOs toward SDGs.

This research strengthens the consequences of the theory of resource-based and literature using ample empirical evidence from the emerging market Pakistan. Consequently, this research aims to support practitioners to modify their strategies of social welfare and environmental initiatives. Alternatively, this study can contribute to motivating responsible authorities and policymakers to provide sufficient resources (financial and non-financial) to NPOs in order to gain SDGs. The government can offer an interest-free or a low level of interest loan to social organizations for social and environmental activities.

\section{Literature and theory}

\subsection{Government incentives and sustainable development goals}

SDGs comprise three major goals; economic, social and environmental. Economics goals are related to improving GDP, employment and propensity of the economy. Social goals are related to a positive change in the quality of life, welfare, health and protection of individuals in societies. Environmental goals describe the clean environment, green practices and reduction of air pollution (Gao et al., 2019). Local institutions play a considerable role in the achievement of SDGs (Aryal et al., 2020) but in particular, attainment of SDGs related to economics can be possible through government institutions and public bodies as compared 
to NPOs. For instance, Boța-Avram et al. (2018) claimed that country-level factors play an important role in SDGs related to economic growth.

Additionally, public and private financial and non-financial institutions also play a key role in sustainable development. In stock and money markets, decision-makers and investors make decisions that influence the economics of sustainable development (Rutkauskas et al., 2008). In this research, we have focused on social and environmental goals while parsimoniously dropped economic goals due to their less concerned with the activities performed by NPOs. Out of several responsibilities of governments, SDGs has deemed a key duty of the government-thereby formulating several strategies to gain it (Aceleanu et al., 2018).

The recent debate of the RBVT claims that organizations with sufficient financial resources tend to perform environmental activities that result in desirable performance. Government incentives such as exemptions, technical assistance and individual credits induce organizations to adopt sustainability initiatives (Blum \& Legey, 2012). Local government needs to provide adequate resources for high economic growth, sustainable development and environmental activities. However, in many countries, financial crises reduce public financial support that creates an imbalance between social activities, sustainable development and public finance (Rodríguez Bolívar et al., 2016). In emerging economies such as China, government incentives and support are very vital for the promotion of sustainability practices, new startups and poverty alleviation (Wu \& Si, 2018). Especially financial incentives and support should be expanded to promote sustainable practices and development in organizations (Rodríguez Bolívar et al., 2016). For instance, Ayuso and Navarrete-Báez (2018) demonstrated that enterprises need sufficient finance for sustainability practices, environmental activities and CSR. A stable financial position of enterprises tends them to serve communities and perform adequate environmental and social activities (Christmann \& Taylor, 2001). However, Wilmshurst and Frost (2001) recommended non-financial support of government for social and sustainable practices.

Similarly, it is deliberated that government support (financial and nonfinancial) are intended to spur the sustainability and environmental initiatives among small enterprises (Sheu \& Chen, 2012). Government incentives (financial and non-financial) are essential for emerging ventures who face significant problems of resource constraints to adopt sustainability initiatives. Such incentives (tax exemption, interest-free credit and technical assistance) encourage enterprises to adopt corporate sustainability performance and enhance their social performance (Pakdeechoho \& Sukhotu, 2018).

Government intervention, incentives and policies are essential for green utilization in emerging economies and developing nations. Huang et al. (2018) demonstrated that government subsidies and public support lead organizations toward the adoption of green practices that are beneficial for sustainable goals. Government policies and incentives affect the stakeholders' perceptions and behaviours in making green buildings and green initiatives in emerging economies s (Hall \& Matos, 2010) such as China (Deng et al., 2018). Government incentives such as lowering taxes, reducing regulatory charges and public imposes environmental and green activities and organizations (Borumand \& Rasti-Barzoki, 2019). Notably, in small organizations, government incentives and fund configure the social benefits and social welfare in a higher ratio as compared to large firms because large firms do not 
implement their strategies directly (Hall \& Matos, 2010). Social services organizations in emerging economies may not have adequate financial resources that are needed for sustainable development. Hence, NGOs need to build strong ties with the government in order to receive satisfactory subsidiaries for sustainability and social practices (Harangozo \& Zilahy, 2015). Therefore:

H1. Access to government incentives (financial and nonfinancial) enables NPOs in community development.

H2. Access to government incentives (financial and nonfinancial) enables NPOs to participate in environmental activities.

\subsection{Government incentives, resources management and SDGs}

The government needs to intervene and regulate the policies and structure for environmental and green initiatives in business industries. It will persuade the attention of organizations to shape their strategies and manage the resources in a way to reduce the costs of total environmental performance (Hafezi \& Zolfagharinia, 2018). An inappropriate amount of subsidies by the government causes insufficient resources allocation that results in a low level of contributions to sustainable development (Kung et al., 2016). The government is responsible for supporting and providing incentives for sustainable and environmental activities. In turn, organizations with adequate resources management abilities contribute to sustainable development practices (Zaman et al., 2017). Government policies, support and intervention, play an important role in the allocation of resources for sustainable practices and environmental safety. Government governance and intervention influence the operational activities and projects performance of organizations in such emerging countries as China. Favourable or good governance can result in satisfactory projects performance (Zhai et al., 2020).

Efficient allocation of resources is indispensable for social, environmental and economic growth. However, to achieve this mission (e.g. sustainable development), government policies and intervention are obligatory because it can shape the management of resources for sustainable activities and environmental cleanness (Cucchiella et al., 2018). NPOs across the globe receive donations, funding, support and incentives for poverty reduction, literacy, health and environmental activities. However, the management of these incentives is vital to benefits the maximum number of poor and needy people. Considering the argument of Pennerstorfer and Neumayr (2017), government support and incentives indirectly influence charitable and do social activities of social and non-governmental organizations via country relation and regulations structure. Government subsidies affect organizational resources, social welfare activities, and environmental activities of organizations. Incentives and policies by government are in deeded helpful for management of resources that help in building a sustainable world. The management of several natural resources is crucial for the reduction of pollution and promotion of sustainable society (Stigson \& Dahlquist, 2017). The government needs to intervene in the management of resources to get the maximum benefits of community and welfare support (Chai \& Schoon, 2016). For instance, Zhu and Yoshikawa (2016) claimed that government directors and managers monitor resources in an efficient way that benefits firms in emerging markets and better management of resources enable 
NPOs to serve more people (Devalkar et al., 2017). Public policies and incentives are fruitful for sustainable development and ecological activities (Doering, 1992).

Environmental and social activities require sufficient resources; financial, human and physical. Hence, NPOs need to manage resources efficiently in order to get maximum benefits. A variety of strategies is needed to cope with sustainable resources for environmental protection and social benefits such as technology and green innovation (Song et al., 2019). Government R\&D findings increase the progress of green innovation and sustainable practices in emerging markets such as China. Hence, the government should facilitate the industries to reduce environmental pollution to create a clean environment (Guo et al., 2018).

Similarly, Onnis (2019) also pointed out that human and strategic management of resources influences sustainability practices in organizations. Resources must be managed and allocated efficiently in order to gain desirable economic development, sustainability and SDGs (Sueyoshi \& Yuan, 2015). For instance, Long et al. (2016) argued that the management of resources such as physical, financial and human is crucial for economic growth and rural development in emerging nations such as China. Allocation and supervision of financial resources is a praiseworthy act to support the poor community in sustainable and social practices. As pointed out by Morgan et al. (2018), sustainable capability and practices are achieved through resource commitment and resources recycling effectively. Hence, organizations should efficiently use the resources in order to configure corporate social responsibility that benefits sustainable practices (Sueyoshi \& Goto, 2019). Workforce, labour and management are used by organizations to allocate resources effectively for adopting and practising ecological and environmental initiatives (Jayaraman et al., 2015). Institutional governance and management are necessary for the sustainable development and federal policies enhance resource management, agriculture production and sustainability practices in different rural sectors and rural areas that result in better environmental practices (Olson, 1992).

In an emerging market such as Pakistan, some NPOs receive funding from international organizations and corporations for the betterment of health, education, environment and wellbeing. If the funds are utilized and managed effectively by the top management of NPOs for social activities, there are high chances to get maximum benefits. Hence, organizations need to use the funds carefully that can benefit all the people instead of targeting a single area. In other words, resource allocation is very prominent in NPOs to benefit many people (Sarikaya \& Buhl, 2020). For instance, environmental activities need adequate financial resources and incentives for organizations first to recognize favourable opportunities to participate in environmental initiatives (Zhang \& Guan, 2018). The government incentives influence innovative activities of organizations and configure their ideas to acquire maximum advantages. Hence, organizations who manage government incentives and resources are argued in a better way will be able to serve communities. The argument is firmly based on Zhang et al. (2018) who scrutinized that political incentives influence the transformation and management of resources in various cities to build better infrastructure. Therefore:

H3. Access to government incentives (financial and nonfinancial) have a positive influence on resource management in NPOs.

H4. Efficient management of resources positively enhances community development and environmental activities in NPOs. 
H5. Resource management mediates the paths between government incentives (financial and nonfinancial) and community development in NPOs.

H6. Resource management mediates the paths between government incentives (financial and nonfinancial) and environmental activities in NPOs.

\section{Methodology}

\subsection{Research design and sample}

A structured questionnaire was used to collect information from NPOs working in the Asian country, Pakistan. It is a quantitative study, and a deductive approach is followed. We surveyed NPOs through a hard copy questionnaire because of the deficiencies of email surveys which deliver a lower response. To ensure the validity and reliability of the survey, we checked and approved the questionnaire from an educational and expert committee. Such kind of approach (e.g. pilot testing) is fruitful when items/questions are built as well as modified. An English language questionnaire was used for data collection because English is spoken as a second language and medium of instruction in Pakistani universities. We distributed 590 questionnaires to NPOs serving different communities of Pakistan. We used a convenience sampling approach because it is difficult to estimate the number of NPOs working in Pakistan. The questionnaire is categorized into two major parts. The first part was about the organization information such as age, size and educational information of the managers. In the second part, we have stated significant variables with options to be filled. However, a cover letter in the top of the survey included, stating data are merely analysed for research purposes because managers are often reluctant and bias to provide accurate and detailed information about their working activities. After several follow-ups, we received 263 usable responses with an adequate response rate of $44.5 \%$. We dropped some responses due to the exceeding number of missing values and incorrectly filled. Table 1 displays the respondents and NPOs information who participated in the survey.

\subsection{Demographics of the NPOs}

Our results show 56 NPOs had less than 100 employees were working, 42 NPOs were those where 101 to 200 employees were working, 62 organizations have employed 201-300 employees, 57 NPOs have employed 301 to 400 employees, and 40 NPOs have 401 to 500 workers. However, only six organizations were those where more than 500 employees were working. Eighty-two organizations have been started their social activities since the last ten years, and below, 75 NPOs were working since 11 to 20 years, 93 NPOs were engaged in welfare activities since 21 to 30 years while only 13 NPOs have been operated since the last 31 or above years. Considering the importance of the educational background of top managers in the success of any organizations, we also asked educational information in the survey. Our results displayed 54 managers who have intermediate or below educational level, 86 managers where bachelor qualified, 98 were master qualified, and 25 have a doctoral degree. 
Table 1. Demographics of the NPOs (source: authors' compilation)

\begin{tabular}{|c|c|c|}
\hline Particular & Frequency & Percentage \\
\hline \multicolumn{3}{|c|}{ Size of NPOs } \\
\hline below 100 employees & 56 & 21.3 \\
\hline $101-200$ & 42 & 16.0 \\
\hline $201-300$ & 62 & 23.6 \\
\hline $301-400$ & 57 & 21.7 \\
\hline $401-500$ & 40 & 15.2 \\
\hline above 500 employees & 6 & 2.3 \\
\hline \multicolumn{3}{|c|}{ Age of NPOs } \\
\hline 10 years and less & 82 & 31.2 \\
\hline $11-20$ years & 75 & 28.5 \\
\hline $21-30$ years & 93 & 35.4 \\
\hline above 31 years & 13 & 4.9 \\
\hline \multicolumn{3}{|c|}{ Qualification of Managers } \\
\hline Intermediate and below & 54 & 20.5 \\
\hline Bachelor & 86 & 32.7 \\
\hline Master & 98 & 37.3 \\
\hline PhD etc. & 25 & 9.5 \\
\hline Total & 263 & 100 \\
\hline
\end{tabular}

\subsection{Measurement of the variables}

Government Incentives: two types of incentives; financial and nonfinancial used in this study. Financial incentives demonstrate the support and funding of government and political organizations for sustainable development while nonfinancial support of government indicates advisory service, information and other non-monetary incentives for social welfare. We used six items for financial incentives and six items for nonfinancial incentives that are used by (Songling et al., 2018). A sample item of financial incentives states "Our government provides sufficient equity funding for social organizations to initiate social projects" and of nonfinancial incentives "Our government provides a wide range of assistance for social activities and social projects".

Resource Management: it illustrates the utilization, efficient use and management of resources to benefit the maximum number of people. We used seven items to measure resource management abilities of the NPOs. These items are used by Ali et al. (2019), but we have slightly modified as per the study requirement. A representative item displays "My organization implements a paperless policy, focuses on economies of scale and cost vs social benefit analysis of resources".

Sustainable Development Goals: we used two primary goals named; community support and environmental activities. These goals are mostly used in the research literature and provide adequate information about sustainable development (Ayuso \& Navarrete-Báez, 2018). 
To measure community support, we used eight items, while twelve items used for environmental activities. A sample item of community support is "We consult stakeholders (employees, suppliers, clients, creditors, associations, NGO, etc.) for decisions concerning local development" and "We consult stakeholders (e.g. employees, suppliers, clients, creditors, etc.) for environment-related decisions" is related to environmental activities.

\subsection{Control variables}

A control variable (or scientific constant) is used to reduce the threat of spurious results in data analysis. Control variables significantly influence experimental results, so they are controlled because of no primary interest of the researcher. In the study, three variables controlled; the size of the NPOs, age of the NPOs and educational background of the managers to test the influence of government incentives on SDGs with resource management as a mediator.

\section{Data analysis}

Data of the sample are passed through several screening tests that are discussed below.

\subsection{Descriptive statistics}

Item wised analysis was done to calculate the descriptive statistics of the data that are shown in Table 2. The results displayed that the majority of the items have their mean values higher than average 3 and overall Standard Deviation (S.D.) of the items is higher than 0.50 . The data of the survey are normally distributed because all the skewness and kurtosis values displayed satisfactory values (below +2 ).

\subsection{Multicollinearity}

Multicollinearity is a threat in the data set where one variable overlaps with another variable in a particular model. We checked the multicollinearity (see Table 3) of the data because it disturbs the results generated from AMOS. Government incentives and resource management are used as independent variables, while community activities and environmental practices are placed as dependent factors. We used mean values in SPSS to check the problem and confirmed the nonattendance of multicollinearity because all the factors displayed acceptable cut-offs; Variance Inflation Factor (VIF) below 3 and tolerance above 0.10.

\subsection{Common method variance}

We used closed-ended questions in the survey to collect data from managers for the hypothesized model that can be affected by the common method variance problem. We checked this threat in SPSS by employing Harman's single factor test with principal component analysis. The test revealed five factors having eigenvalues above 1, and the first factor exhibited only $24.16 \%$ variance. Hence, the data revealed that there is no common method variance issue because the variance of the first factor is not exceeded by $50 \%$ (MacKenzie \& Podsakoff, 
2012). Still, Harman's one-factor test has been criticized for being lack of validity and reliability in cross-sectional data. Hence, we evaluated another approach named "common latent factor" in AMOS to know the common method variance issue. We checked the influence of a common latent factor on the measurement model and compared the results of the two models (one run with common latent factor and one is without the common latent factor). The findings did not show any threat in this study, thereby confirming the absence of common method variance problem.

\subsection{Non-response bias}

To check the non-response bias, researchers compare primary constructs among late and early responses in a data set (Armstrong \& Overton, 1977). Early responses mean the responses received immediately (without reminder), and late response means the responses received after the reminder. An independent $t$-test used to compare the two groups (early responses and late responses) based on the mean score of GFSP, GNFS, resource management and SDGs. The test yielded no statistically significant difference between the early and late responses $(\mathrm{p}=0.11)$ because the $\mathrm{P}$-value is higher than 0.05 . Hence we confirm that there is no threat of non-response bias in data.

Table 2. Descriptive statistics (source: authors' compilation)

\begin{tabular}{|l|c|c|c|c|c|c|}
\hline \multicolumn{1}{|c|}{ Items } & Minimum & Maximum & Mean & S.D. & Skewness & Kurtosis \\
\hline gfsp1 & 2 & 5 & 3.40 & 0.679 & -0.168 & -0.324 \\
\hline gfsp2 & 1 & 5 & 3.40 & 0.749 & -0.968 & 1.213 \\
\hline gfsp3 & 2 & 5 & 3.50 & 0.641 & -0.299 & -0.234 \\
\hline gfsp4 & 1 & 5 & 3.42 & 0.772 & -0.890 & 1.094 \\
\hline gfsp5 & 2 & 5 & 3.45 & 0.634 & -0.365 & -0.358 \\
\hline gfsp6 & 1 & 5 & 3.38 & 0.777 & -0.679 & 0.952 \\
\hline gnfsp1 & 2 & 5 & 3.45 & 0.685 & -0.208 & -0.274 \\
\hline gnfsp2 & 2 & 5 & 3.52 & 0.681 & -0.500 & -0.155 \\
\hline gnfsp3 & 2 & 5 & 3.48 & 0.681 & -0.216 & -0.233 \\
\hline gnfsp4 & 2 & 5 & 3.48 & 0.676 & -0.321 & -0.252 \\
\hline gnfsp5 & 2 & 5 & 3.50 & 0.693 & -0.423 & -0.208 \\
\hline gnfsp6 & 2 & 5 & 3.48 & 0.659 & -0.246 & -0.240 \\
\hline rm1 & 1 & 5 & 3.43 & 0.547 & -0.197 & 0.042 \\
\hline rm2 & 1 & 5 & 3.46 & 0.577 & -0.489 & 0.141 \\
\hline rm3 & 1 & 5 & 3.46 & 0.571 & -0.354 & 0.174 \\
\hline rm4 & 1 & 5 & 3.48 & 0.585 & -0.711 & 0.988 \\
\hline rm5 & 2 & 5 & 3.48 & 0.551 & -0.246 & -0.915 \\
\hline rm6 & 1 & 5 & 3.48 & 0.578 & -0.440 & 0.212 \\
\hline rm7 & 2 & 5 & 3.46 & 0.544 & 0.001 & -0.984 \\
\hline cmty1 & 1 & 5 & 3.58 & 0.648 & -0.589 & 0.598 \\
\hline & & & & & & \\
\hline
\end{tabular}


End of Table 2

\begin{tabular}{|l|c|c|c|c|c|c|}
\hline \multicolumn{1}{|c|}{ Items } & Minimum & Maximum & Mean & S.D. & Skewness & Kurtosis \\
\hline cmty2 & 1 & 5 & 3.48 & 0.658 & -0.636 & 0.692 \\
\hline cmty3 & 1 & 5 & 3.59 & 0.611 & -0.600 & 0.716 \\
\hline cmty4 & 1 & 5 & 3.48 & 0.664 & -0.513 & 0.691 \\
\hline cmty5 & 1 & 5 & 3.60 & 0.633 & -0.536 & 0.702 \\
\hline cmty6 & 1 & 5 & 3.52 & 0.676 & -0.698 & 0.766 \\
\hline cmty7 & 1 & 5 & 3.55 & 0.657 & -0.664 & 0.990 \\
\hline cmty8 & 1 & 5 & 3.46 & 0.692 & -0.566 & 0.484 \\
\hline envt1 & 2 & 5 & 3.59 & 0.604 & -0.993 & 0.277 \\
\hline envt2 & 1 & 5 & 3.60 & 0.603 & -1.115 & 1.091 \\
\hline envt3 & 2 & 5 & 3.60 & 0.589 & -0.978 & 0.282 \\
\hline envt4 & 1 & 5 & 3.53 & 0.641 & -0.853 & 0.479 \\
\hline envt5 & 2 & 5 & 3.54 & 0.616 & -0.697 & -0.121 \\
\hline envt6 & 1 & 5 & 3.55 & 0.634 & -0.997 & 0.639 \\
\hline envt7 & 2 & 5 & 3.52 & 0.623 & -0.653 & -0.190 \\
\hline envt8 & 1 & 5 & 3.52 & 0.659 & -0.885 & 0.404 \\
\hline envt9 & 2 & 5 & 3.51 & 0.653 & -0.657 & -0.174 \\
\hline envt10 & 1 & 5 & 3.55 & 0.657 & -0.746 & 0.511 \\
\hline envt11 & 2 & 5 & 3.55 & 0.590 & -0.707 & -0.198 \\
\hline envt12 & 1 & 5 & 3.52 & 0.604 & -0.776 & 0.471 \\
\hline
\end{tabular}

Table 3. Multicollinearity (source: authors' compilation)

\begin{tabular}{|l|c|c|c|c|}
\hline \multicolumn{1}{|c|}{ Variables } & \multicolumn{2}{c|}{ Community } & \multicolumn{2}{c|}{ Environment } \\
\hline & Tolerance & VIF & Tolerance & VIF \\
\hline GFSP & 0.826 & 1.211 & 0.825 & 1.211 \\
\hline GNFSP & 0.953 & 1.049 & 0.913 & 1.048 \\
\hline Resource Management & 0.891 & 1.261 & 0.791 & 1.265 \\
\hline
\end{tabular}

Note: GFSP = Government Financial Support, GNFSP = Government Nonfinancial Support.

\section{Measurement model}

To ensure the validity of the data, first, we analysed validity and reliability in confirmatory factor analysis, and then structural model in AMOS was applied for testing hypothesized relationship among the variables. Compared to other statistical tests and software, SEM gives the most significant advantage to simultaneously measure the association between potential variables in a single model (Hair et al., 2017). Additionally, SEM supports testing complexed relationship in a single model. Structural equation modelling (SEM) contains a diverse set of statistical models and methods that fit to constructing data analyses (Hu \& Bentler, 1999). In statistics, such models seek to identify and explain the mechanism or process that underlies a relationship between independent and dependent variables via the inclusion of a third hypothetical (mediator) determinant. 
In addition, the convergent validity and discriminant validity are superior benefits to be gained in SEM as compared to SPSS.

The indicators; ( $\chi 2 / \mathrm{df}), \mathrm{GFI}, \mathrm{AGFI}$, TLI, NFI, RMR and RMSEA are used as fit indexes to evaluate models. In this model, standardized factor loading of the items, convergent validity, discriminant validity, composite reliability is evaluated. In the first attempt of the model, there were redundancy between e10 and e12, e15 and e16, e13 and e14, e25 and e26, e24 and e25, e22 and e23, e20 and e22, e20 and e24, e38 and 39, e36 and e38, e34 and e36, e31 and e33, e28 and e29 and e29 and e30. Hence, we draw covariance between these items and run the model again. The second attempt of the model provided satisfactory modification indicates (MI, see Table 4 ) and adequate fitness value (see Table 5) for $\chi 2 / \mathrm{df}=1.899$ that is less than 3 , as suggested by (Bentler, 1990). The other fit statistics; GFI $=0.80, \mathrm{AGFI}=0.80$, TLI $=$ 0.91 and NFI $=0.84$ are closed to 1 or greater than 0.90 revealed suitable values (Hayes \& Scharkow, 2013). Similarly, RMR $=0.022$ and RMSEA $=0.059$ also generated acceptable values (below 0.09) as per the suggestions of (Hooper et al., 2007). All the items are significant $(\mathrm{p}<0.001)$, as shown in Table 6 , and no multicollinearity issue is reported with other factors.

Validity and Reliability: After ensuring model fitness indicators, we evaluated convergent validity, discriminant validity and composite reliability of the factors that are shown in Table 6 . The convergent validity is calculated by taking the square of all the standardized values of items loaded on a particular variable. After doing so, we found that all the variables have acceptable (above 0.50) convergent validity, confirming that the Average Variance Extracted (AVE) by the factors is adequate (Fornell \& Larcker, 1981). The discriminant validity is simply calculated by taking the square root of AVE for each factor. The value above 0.70 indicates uniqueness in the factors and confirms that the items of a particular variable are not overlapping with each other (Hair et al., 2010). The analysis met this condition and displayed desirable value (above 0.70 ) of discriminant validity in the model. The composite reliability is assessed to check the internal consistency among the items toward a specific variable. A value greater than 0.70 is sufficient to confirm internal consistency (Nunnally \& Bernstein, 1994), and we also achieved this condition. Hence, the fitness, validity and reliability criteria are met in the measurement model. Additionally, all the variables show a significant positive correlation $\left({ }^{\star} \mathrm{p}<0.05,{ }^{\star *} \mathrm{p}<0.01\right)$ as presented in Table 7 .

Table 4. Modification indices (source: authors' compilation)

\begin{tabular}{|c|c|c|c|c|c|c|c|c|c|c|c|c|c|c|}
\hline \multicolumn{2}{|c|}{ Items } & M.I. & $\begin{array}{c}\text { Par } \\
\text { Change }\end{array}$ & \multicolumn{2}{|c|}{ Items } & \multicolumn{2}{|c|}{ M.I. } & \multicolumn{2}{c|}{$\begin{array}{c}\text { Par } \\
\text { Change }\end{array}$} & \multicolumn{2}{|c|}{ Items } & M.I. & $\begin{array}{c}\text { Par } \\
\text { Change }\end{array}$ \\
\hline e1 & - & e5 & 9.707 & -0.040 & e9 & - & e20 & 6.107 & 0.025 & e22 & - & e24 & 7.288 & 0.031 \\
\hline e1 & - & e4 & 10.165 & 0.042 & e10 & - & e39 & 5.062 & -0.018 & e23 & - & e37 & 4.729 & -0.027 \\
\hline e1 & - & e3 & 10.803 & 0.038 & e10 & - & e38 & 6.435 & 0.021 & e24 & - & e36 & 5.457 & -0.021 \\
\hline e1 & - & e2 & 9.511 & -0.037 & e11 & - & e12 & 4.445 & -0.026 & e24 & - & e27 & 10.74 & -0.033 \\
\hline e2 & - & e6 & 16.844 & 0.049 & e12 12 & - & e31 & 4.216 & 0.025 & e25 & - & RsrcMgt & 4.884 & -0.019 \\
\hline e2 & - & e 5 & 10.900 & 0.039 & e12 & - & e29 & 5.252 & -0.015 & e25 & - & GFSP & 4.523 & 0.029 \\
\hline e2 & - & e3 & 11.341 & -0.037 & e13 & - & e18 & 11.609 & -0.026 & e26 & - & RsrcMgt & 6.292 & 0.026 \\
\hline
\end{tabular}


End of Table 4

\begin{tabular}{|c|c|c|c|c|c|c|c|c|c|c|c|c|c|c|}
\hline \multicolumn{3}{|c|}{ Items } & \multirow{2}{*}{$\begin{array}{c}\text { M.I. } \\
12.590\end{array}$} & \multirow{2}{*}{$\begin{array}{c}\text { Par } \\
\text { Change }\end{array}$} & \multicolumn{3}{|c|}{ Items } & \multirow{2}{*}{$\begin{array}{l}\text { M.I. } \\
4.686\end{array}$} & \multirow{2}{*}{$\begin{array}{c}\text { Par } \\
\text { Change }\end{array}$} & \multicolumn{3}{|c|}{ Items } & \multirow{2}{*}{$\begin{array}{l}\text { M.I. } \\
7.599\end{array}$} & \multirow{2}{*}{$\begin{array}{c}\text { Par } \\
\text { Change }\end{array}$} \\
\hline e3 & - & e24 & & & e14 & - & e39 & & & e26 & - & e27 & & \\
\hline e3 & - & e18 & 10.353 & -0.036 & e14 & - & e36 & 6.613 & -0.017 & e27 & - & RsrcMgt & 5.029 & -0.021 \\
\hline e3 & - & e16 & 6.320 & 0.028 & e14 & - & e18 & 10.147 & 0.026 & e27 & - & e36 & 4.465 & 0.016 \\
\hline e3 & - & e6 & 10.953 & -0.040 & e14 & - & e17 & 4.261 & -0.016 & e28 & - & e37 & 7.643 & -0.023 \\
\hline e3 & - & e5 & 6.696 & 0.030 & e14 & - & e16 & 12.580 & 0.029 & $\mathrm{e} 28$ & - & e36 & 4.341 & -0.012 \\
\hline e4 & - & e32 & 4.698 & 0.030 & e14 & - & e15 & 4.375 & -0.015 & e28 & - & e35 & 6.637 & 0.012 \\
\hline $\mathrm{e} 4$ & - & e22 & 5.325 & 0.027 & e15 & - & e28 & 7.784 & -0.017 & e28 & - & e31 & 4.001 & -0.016 \\
\hline $\mathrm{e} 4$ & - & $\mathrm{e} 21$ & 7.584 & -0.033 & e15 & - & e21 & 5.124 & 0.022 & $\mathrm{e} 28$ & - & e30 & 9.999 & 0.018 \\
\hline e4 & - & e17 & 5.015 & 0.025 & e16 & - & e26 & 8.669 & 0.032 & e29 & - & Comm. & 5.566 & 0.015 \\
\hline e4 & - & e15 & 5.501 & -0.024 & e16 & - & e25 & 11.139 & -0.031 & e29 & - & GFSP & 13.473 & -0.036 \\
\hline e4 & - & e5 & 10.685 & -0.042 & e16 & - & e19 & 4.690 & -0.018 & e30 & - & GFSP & 5.088 & 0.031 \\
\hline e5 & - & e23 & 5.073 & -0.027 & e16 & - & e18 & 14.401 & 0.041 & e31 & - & e37 & 7.816 & 0.038 \\
\hline e5 & - & e19 & 4.309 & -0.019 & e16 & - & e17 & 8.859 & -0.030 & e31 & - & e36 & 10.764 & 0.030 \\
\hline e5 & - & e15 & 4.025 & 0.020 & e17 & - & e26 & 10.720 & -0.033 & e31 & - & e32 & 7.598 & -0.039 \\
\hline e6 & - & e38 & 4.834 & 0.020 & e17 & - & $\mathrm{e} 25$ & 4.849 & 0.019 & e32 & - & e38 & 4.811 & 0.022 \\
\hline e6 & - & e34 & 6.323 & 0.030 & e17 & - & e19 & 6.808 & 0.020 & e32 & - & e36 & 14.216 & 0.039 \\
\hline e6 & - & e27 & 9.257 & -0.033 & e17 & - & e18 & 10.182 & -0.033 & e32 & - & e35 & 4.691 & -0.019 \\
\hline e6 & - & $\mathrm{e} 22$ & 4.148 & 0.025 & e20 & - & e37 & 6.259 & 0.032 & e32 & - & e34 & 4.162 & 0.027 \\
\hline e6 & - & e16 & 9.807 & -0.038 & e20 & - & e28 & 4.221 & -0.015 & e33 & - & e37 & 4.505 & 0.029 \\
\hline e8 & - & e32 & 4.091 & 0.028 & e20 & - & e26 & 8.509 & 0.032 & e34 & - & e39 & 5.183 & -0.018 \\
\hline e8 & - & $\mathrm{e} 21$ & 4.383 & -0.025 & $\mathrm{e} 20$ & - & e21 & 16.731 & -0.047 & e34 & - & e38 & 14.214 & 0.031 \\
\hline e8 & - & e16 & 4.299 & -0.024 & e21 & - & GNFSP & 7.276 & -0.044 & e35 & - & e38 & 5.066 & -0.012 \\
\hline e8 & - & e12 & 6.400 & 0.030 & e21 & - & e24 & 5.795 & 0.028 & e36 & - & e37 & 7.378 & 0.027 \\
\hline e8 & - & e10 & 8.962 & 0.034 & $\mathrm{e} 21$ & - & e22 & 4.887 & -0.025 & e37 & - & e38 & 15.257 & -0.037 \\
\hline e8 & - & e9 & 9.601 & -0.033 & e22 & - & e37 & 8.953 & -0.038 & & & & & \\
\hline
\end{tabular}

Table 5. Model fits (source: authors' compilation)

\begin{tabular}{|l|c|c|c|c|c|c|c|c|}
\hline \multicolumn{1}{|c|}{ Models } & $\chi 2 / \mathrm{df}$ & RMR & RMSEA & GFI & AFG & NFI & TLI & CFI \\
\hline 1 Measurement Model & 1.899 & 0.022 & 0.059 & 0.80 & 0.80 & 0.84 & 0.91 & 0.92 \\
\hline 2 Structural Model & 2.359 & 0.054 & 0.079 & 0.97 & 0.92 & 0.85 & 0.80 & 0.90 \\
\hline Acceptable Range & $<3$ & $<0.09$ & $<0.08$ & $>0.90$ & $>0.90$ & $>0.90$ & $>0.90$ & $>0.90$ \\
\hline
\end{tabular}

Note: 1 shows the model fits of CFA (measurement model), 2 displays the fitness of model for structural model, $\mathrm{RMR}=$ room mean square residual, RMSEA $=$ root mean square residual errors of approximation, GFI = goodness of fit index, AGFI = adjusted goodness of fit index, NFI = normative fit index, TLI $=$ Trucker-Lewis index, CFI = comparative fit index. The acceptance values of the model fit vary and no standard values are stated. 
Table 6. Items and Standardized loading (source: authors' compilation)

\begin{tabular}{|c|c|c|}
\hline Items & Descriptions & Estimate \\
\hline & Government Financial Support & \\
\hline gfsp6 & $\begin{array}{l}\text { We access sufficient equity funding provided by the government for social } \\
\text { organizations to initiate social projects }\end{array}$ & 0.85 \\
\hline gfsp5 & $\begin{array}{l}\text { Our government encourages foreign organizations to provide financial } \\
\text { incentives to the host NPOs for the local community. In results, foreign funds } \\
\text { for social welfare easily accessed }\end{array}$ & 0.69 \\
\hline gfsp4 & $\begin{array}{l}\text { In our country, members (other than founders) of social organizations can } \\
\text { access sufficient funds offered by the government }\end{array}$ & 0.89 \\
\hline gfsp3 & $\begin{array}{l}\text { In our country, there are sufficient government financial subsidies available for } \\
\text { social organizations, and we have easy access to it }\end{array}$ & 0.61 \\
\hline gfsp2 & $\begin{array}{l}\text { We can easily access interest-free and a low level of interest charged debt/loan } \\
\text { funding }\end{array}$ & 0.83 \\
\hline \multirow[t]{2}{*}{ gfsp1 } & We can easily access government short term and long term financial services & 0.76 \\
\hline & Government Nonfinancial Support & \\
\hline gnfsp6 & We can access public support, house, hotels and parks when need & 0.93 \\
\hline gnfsp5 & $\begin{array}{l}\text { Our government helps all the NPOs and almost every social organization who } \\
\text { needs help }\end{array}$ & 0.79 \\
\hline gnfsp4 & $\begin{array}{l}\text { Our government encourages us to help impoverished communities and } \\
\text { societies by providing free infrastructure }\end{array}$ & 0.86 \\
\hline gnfsp3 & $\begin{array}{l}\text { There are an adequate number of public advisory programs on health and } \\
\text { safety, education, poverty, social entrepreneurship and foods for NPOs and we } \\
\text { can easily access }\end{array}$ & 0.66 \\
\hline gnfsp2 & $\begin{array}{l}\text { Our government supports us in building science parks and social incubators } \\
\text { in poor communities }\end{array}$ & 0.77 \\
\hline \multirow[t]{2}{*}{ gnfsp1 } & $\begin{array}{l}\text { We access a wide range of assistance provided by the government for social } \\
\text { activities and social projects }\end{array}$ & 0.62 \\
\hline & Resource Management & \\
\hline $\mathrm{rm} 7$ & $\begin{array}{l}\text { My organization sets specific objectives and implements specific programs to } \\
\text { optimize resource usage in order to benefits more and more people }\end{array}$ & 0.79 \\
\hline rm6 & $\begin{array}{l}\text { We have qualified managers who efficiently manage financial and non- } \\
\text { financial resources provided by public bodies and financial institutions }\end{array}$ & 0.77 \\
\hline rm5 & $\begin{array}{l}\text { My organization encourages the utilization of resources in such a way to get } \\
\text { maximum outputs via minimum inputs }\end{array}$ & 0.79 \\
\hline $\mathrm{rm} 4$ & $\begin{array}{l}\text { My organization implements a paperless policy, focuses on economies of scale } \\
\text { and cost vs social benefit analysis of resources. }\end{array}$ & 0.70 \\
\hline $\mathrm{rm} 3$ & $\begin{array}{l}\text { My organization attempts to optimize resource usage through regular review } \\
\text { of the process flow }\end{array}$ & 0.75 \\
\hline $\mathrm{rm} 2$ & $\begin{array}{l}\text { Priority is given to products with green attributes, such as those that are } \\
\text { recyclable, repairable, reusable, renewable, biodegradable, energy saving }\end{array}$ & 0.72 \\
\hline $\mathrm{rm} 1$ & $\begin{array}{l}\text { We do not have formal policies and structures for the usage of financial and } \\
\text { non-financial incentives offered by the local government for new projects }\end{array}$ & 0.85 \\
\hline
\end{tabular}


End of Table 6

\begin{tabular}{|c|c|c|}
\hline Items & Descriptions & Estimate \\
\hline & Community Development & \\
\hline cmtyl & $\begin{array}{l}\text { We communicate actions among internal stakeholders (e.g. meetings with } \\
\text { staff, intranet, reports, etc.) }\end{array}$ & 0.63 \\
\hline cmty2 & We communicate actions to external stakeholders (e.g. website, reports, etc.) & 0.79 \\
\hline cmty3 & $\begin{array}{l}\text { We have established metrics that monitor (e.g. amounts spent, allocated time, } \\
\text { types of beneficiaries, etc.) to benefit the communities }\end{array}$ & 0.65 \\
\hline cmty 4 & We favour local suppliers in the regions & 0.80 \\
\hline cmty 5 & We favour job creation in the regions & 0.65 \\
\hline cmty6 & $\begin{array}{l}\text { We offer internships and contribute to student training in different } \\
\text { communities }\end{array}$ & 0.78 \\
\hline cmty7 & $\begin{array}{l}\text { We consult other stakeholders (employees, suppliers, clients, creditors, } \\
\text { associations, NGO, etc.) for decisions concerning local development }\end{array}$ & 0.65 \\
\hline \multirow[t]{2}{*}{ cmty 8} & $\begin{array}{l}\text { We contribute to community cultural, sporting or teaching activities (public } \\
\text { organizations or associations with social, cultural, sporting or teaching } \\
\text { activities) }\end{array}$ & 0.88 \\
\hline & Environmental Practices & \\
\hline envt1 & $\begin{array}{l}\text { We communicate actions to internal stakeholders (e.g. meetings with staff, } \\
\text { intranet, reports, etc.) }\end{array}$ & 0.85 \\
\hline envt2 & $\begin{array}{l}\text { We communicate your actions to your external stakeholders (e.g. website, } \\
\text { reports, etc.) }\end{array}$ & 0.81 \\
\hline envt3 & $\begin{array}{l}\text { We have established metrics that you monitor (e.g. regarding risks, levels of } \\
\text { pollution, of energy consumption, waste, etc.) }\end{array}$ & 0.71 \\
\hline envt4 & $\begin{array}{l}\text { We consult stakeholders (e.g. employees, suppliers, clients, creditors, etc.) for } \\
\text { environment-related decisions }\end{array}$ & 0.66 \\
\hline envt5 & $\begin{array}{l}\text { We integrate environmental considerations in the conception and } \\
\text { development of products and services in all phases of their life cycle (eco- } \\
\text { conception and the analysis of the life cycle) }\end{array}$ & 0.59 \\
\hline envt6 & $\begin{array}{l}\text { We integrate environmental considerations in your purchase decisions and the } \\
\text { evaluation of your suppliers }\end{array}$ & 0.64 \\
\hline envt7 & $\begin{array}{l}\text { We encourage and support your employees to use alternatives means of } \\
\text { transportation to commute instead of single-occupancy cars (e.g. rideshare, } \\
\text { public transport, bicycle, etc.) }\end{array}$ & 0.68 \\
\hline envt8 & $\begin{array}{l}\text { We give priority to less polluting vehicles and modes of transportation and/or } \\
\text { optimize your distribution network }\end{array}$ & 0.95 \\
\hline envt9 & We give priority to more water and energy-efficient equipment & 0.82 \\
\hline envt10 & $\begin{array}{l}\text { We raise awareness and/or train of the employees in water and/or energy } \\
\text { conservation }\end{array}$ & 0.69 \\
\hline envt11 & We give priority to reusable, used or recycled materials. & 0.62 \\
\hline envt12 & $\begin{array}{l}\text { We separate your garbage and waste (recycling of materials: paper, plastic, } \\
\text { glass and metal) }\end{array}$ & 0.72 \\
\hline
\end{tabular}

Note: *Reversed coded. 
Table 7. Correlations (source: authors' compilation)

\begin{tabular}{|l|c|c|c|c|c|c|c|c|c|c|c|}
\hline \multicolumn{1}{|c|}{ Variables } & AVE & C.R. & Alpha & Size & Age & Education & GFSP & GNFSP & GNFSP & Comm. & Envt. \\
\hline Size & - & - & - & - & & & & & & & \\
\hline Age & - & - & - & $0.281^{\star *}$ & - & & & & & & \\
\hline Education & - & - & - & $0.151^{*}$ & 0.054 & - & & & & & \\
\hline GFSP & 0.60 & 0.90 & 0.905 & $0.156^{*}$ & 0.040 & 0.097 & $(0.77)$ & & & & \\
\hline GNFSP & 0.61 & 0.90 & 0.907 & $0.156^{*}$ & 0.099 & 0.099 & 0.060 & $(0.78)$ & & & \\
\hline Resource Mgt & 0.59 & 0.90 & 0.908 & $0.137^{\star}$ & 0.120 & $0.122^{*}$ & $0.416^{* *}$ & $0.215^{* *}$ & $(0.77)$ & & \\
\hline Community & 0.54 & 0.90 & 0.906 & $0.176^{* *}$ & 0.093 & 0.031 & $0.122^{*}$ & $0.166^{* *}$ & $0.205^{* *}$ & $(0.73)$ & \\
\hline Environment & 0.54 & 0.93 & 0.936 & $0.246^{* *}$ & $0.345^{* *}$ & $0.122^{*}$ & $0.174^{* *}$ & $0.260^{* *}$ & $0.276^{* *}$ & $0.215^{* *}$ & $(073)$ \\
\hline
\end{tabular}

Note: AVE $=$ Average Variance Extracted, CR $=$ Composite Reliability, Discriminant validity is shown above the correlation values in the brackets, ${ }^{* *}$ Correlation is significant at the 0.01 level (2-tailed).* Correlation is significant at the 0.05 level (2-tailed). GFSP $=$ Government Financial Support, GNFSP $=$ Government Nonfinancial Support.

\section{Structural model}

The hypothesized model is tested via Structural Equation Modelling (SEM) using AMOS (see Figure 1). One of the most fruitful benefits of AMOS is testing hypotheses (as many) in a single model. Hence, we performed a structural model (on mean values of the factors) to test the hypothesized relationships. First, we certified the fitness of the model such as $\chi 2$ / $\mathrm{df}=2.359$, which is less than 3 , indicating the satisfactory value of the model fit. Moreover, $\mathrm{GFI}=0.97, \mathrm{AGFI}=0.92$, TLI $=0.91$, NFI $=0.85$ and $\mathrm{CFI}=0.92$ displayed adequate values (above 0.90 ). Also, RMR $=0.054$ and RMSEA $=0.079$ delivered satisfactory values (below 0.09 ) as per the propositions of (Hayes \& Scharkow, 2013).

The results (see Table 8 ) generated from the model display that government financial and nonfinancial incentives have not a direct significant influence on community practices in NPOs $(\beta=0.034, p>0.05$ and $\beta=0.129, p>0.05)$ respectively and thus rejecting H1. Government financial incentive does not significantly impact environmental activities $(\beta=0.067$,

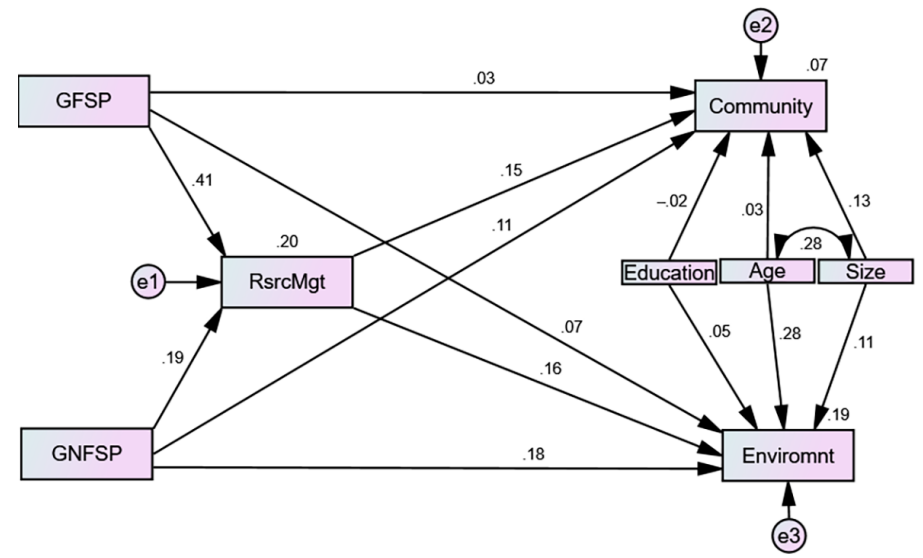

Figure 1. Structural model 
Table 8. Hypotheses Testing (source: authors' compilation)

\begin{tabular}{|l|c|c|c|}
\hline \multicolumn{1}{|c|}{ Hypotheses } & Direct effect & $\begin{array}{c}\text { Indirect effect } \\
\text { (via Resource Mgt.) }\end{array}$ & Total effect \\
\hline Community $\leftarrow$ GFSP & 0.034 & $0.060^{\star}$ & 0.095 \\
\hline Community $\leftarrow$ GNFSP & 0.129 & $0.028^{\star}$ & 0.140 \\
\hline Environment $\leftarrow$ GFSP & 0.067 & $0.066^{* *}$ & $0.132^{\star}$ \\
\hline Environment $\leftarrow$ GNFSP & $0.177^{* *}$ & $0.031^{* *}$ & $0.208^{* *}$ \\
\hline Resource Mgt. $\leftarrow$ GFSP & $0.406^{* *}$ & - & $0.406^{* *}$ \\
\hline Resource Mgt. $\leftarrow$ GNFSP & $0.191^{* *}$ & - & $0.191^{* *}$ \\
\hline Community $\leftarrow$ Resource Mgt. & $0.148^{\star}$ & - & $0.148^{\star}$ \\
\hline Environment $\leftarrow$ Resource Mgt. & $0.162^{* *}$ & - & $0.162^{* *}$ \\
\hline Community $\leftarrow$ Size of NPOs & 0.129 & - & - \\
\hline Community $\leftarrow$ Age of NPOs & 0.028 & - & - \\
\hline Community $\leftarrow$ Education of Managers & -0.023 & - & - \\
\hline Environment $\leftarrow$ Education of Managers & 0.105 & - & - \\
\hline Environment $\leftarrow$ Age of NPOs & $0.281^{\star}$ & - & - \\
\hline Environment $\leftarrow$ Education of Managers & 0.050 & - & - \\
\hline
\end{tabular}

Note: GFSP $=$ Government Financial Support, GNFSP $=$ Government Nonfinancial Support. ${ }^{* \star}$ p-value $<$ $0.01,{ }^{*} \mathrm{p}$-value $<0.05$.

$\mathrm{p}>0.05)$ but nonfinancial incentive significantly enhances environmental practices in NPOs $(\beta=0.177, p<0.05)$, partially support $H 2$. Both financial and nonfinancial incentives significantly influence resource management in NPOs $(\beta=0.406, \mathrm{p}<0.05$ and $\beta=0.191, \mathrm{p}<0.05)$, supporting H3. Similarly, efficient management of resources significantly contributes to community and environmental practices in NPOs $(\beta=0.148, \mathrm{p}<0.05$ and $\beta=0.142, \mathrm{p}<0.05)$, hence $\mathrm{H} 4$ is supported.

Considering the mediating role of resource management, the study revealed that the indirect influence of government incentives (financial and nonfinancial) on community practices is significant $(\beta=0.06, \mathrm{p}<0.05$ and $\beta=0.028, \mathrm{p}<0.05)$ and the direct impact is insignificant. It confirms that resource management fully mediates the bath between government incentives and community practices in NPOs. The indirect influence of public incentives (financial and nonfinancial) on environmental practices is significant $(\beta=0.066, \mathrm{p}<0.05$ and $\beta=0.031, p<0.05$ ), however the direct influence of financial incentive is not significant $(\beta=0.067, \mathrm{p}>0.05)$ but the impact of nonfinancial incentive remained significant $(\beta=0.406, \mathrm{p}<0.05$ and $(\beta=0.177, \mathrm{p}<0.05)$, we deemed it as a partial mediating role of resource management between government incentives and environmental practices. In the controlled factors, we found that only age of the NPOs has a significant role while the size of the organizations and educational background do not show any significant role. $\mathrm{R}$ square in the structural model directs only $7 \%$ of the variance in community practices while $19 \%$ of the variance in environmental practices that are explained by government incentives in the presence of resource management as a mediating variable (Table 10). 


\section{Robustness checks}

We also performed regression analysis in SPSS to check the influence of government incentives on SDGs with a mediating role of resource management in NPOs. We evaluated two models (see Table 9) of which one for the dependent variable of community practices and other for the dependent variable environmental activities. We entered the control variables; size and age of the NPOs and qualification of managers in the first step (Model 1), government incentives in the second step (Model 2) and resource management in the third step (Model 3). The findings are slightly different from the results of the structural model.

For instance, regression analysis displayed somewhat a partial mediating role of resource management between government incentives (financial and nonfinancial) and contribution to SDGs. However, the structural model displays a fully mediating role of resource management between government incentives and contribution to SDGs. Similarly, in the control variables, only age of NPOs displayed a significant role in the environmental model while regression revealed the size of NPOs in community and environment as well as the age of NPOs in the environmental model. Overall, there is a slight difference between no significant change reported between the results of structural and regression models.

Table 9. Regression analyses (source: authors' compilation)

\begin{tabular}{|c|c|c|c|c|c|c|}
\hline \multirow{2}{*}{ Models } & \multicolumn{3}{|c|}{ Community Development } & \multicolumn{3}{|c|}{ Environmental Practices } \\
\hline & $\beta$ & $\mathrm{R}^{2}$ & $\mathrm{R}^{2} \Delta$ & $\beta$ & $\mathrm{R}^{2}$ & $\mathrm{R}^{2} \Delta$ \\
\hline Model 1 & $2.432^{\star \star}$ & 0.033 & $0.033^{\star}$ & $2.704^{\star \star}$ & 0.150 & $0.150^{\star \star}$ \\
\hline Size & $0.044^{\star}$ & & & $0.052^{*}$ & & \\
\hline Age & 0.020 & & & $0.162^{\star}$ & & \\
\hline Education & 0.002 & & & 0.046 & & \\
\hline Model 2 & $1.960^{\star *}$ & 0.060 & $0.027^{\star}$ & $1.827^{\star *}$ & 0.206 & $0.057^{* *}$ \\
\hline Size & $0.035^{\star}$ & & & 0.037 & & \\
\hline Age & 0.017 & & & $0.155^{\star \star}$ & & \\
\hline Education & -0.006 & & & 0.032 & & \\
\hline GFSP & 0.057 & & & $0.101^{*}$ & & \\
\hline GNFSP & $0.090^{\star}$ & & & $0.171^{\star *}$ & & \\
\hline Model 3 & $1.716^{* *}$ & 0.077 & $0.017^{\star}$ & $1.488^{\star *}$ & 0.226 & $0.020^{*}$ \\
\hline Size & $0.035^{\star}$ & & & 0.036 & & \\
\hline Age & 0.012 & & & $0.149^{\star \star}$ & & \\
\hline Education & -0.009 & & & 0.027 & & \\
\hline GFSP & 0.021 & & & 0.052 & & \\
\hline GNFSP & 0.073 & & & $0.147^{\star \star}$ & & \\
\hline RsrcMgt & $0.139^{\star}$ & & & $0.193^{*}$ & & \\
\hline
\end{tabular}

Note: GFSP = Government Financial Support, GNFSP = Government Nonfinancial Support. 
Table 10. Hypotheses remarks (source: authors' compilation)

\begin{tabular}{|c|c|c|c|c|}
\hline $\begin{array}{l}\text { Sr. } \\
\text { No }\end{array}$ & Hypotheses & Proposed & Our Results & Remarks \\
\hline \multirow{2}{*}{$\mathrm{H} 1$} & Access to GFI $\rightarrow$ community development & +Significant & + Insignificant & Rejected \\
\hline & Access to GNFI $\rightarrow$ community development & + Significant & +Insignificant & \\
\hline \multirow[t]{2}{*}{$\mathrm{H} 2$} & Access to GFI $\rightarrow$ environmental activities & + Significant & +Insignificant & $\begin{array}{l}\text { Partially } \\
\text { Accepted }\end{array}$ \\
\hline & Access to GNFI $\rightarrow$ environmental activities & & +Significant & \\
\hline \multirow{2}{*}{ H3 } & Access to GFI $\rightarrow$ resource management & + Significant & + Significant & Accepted \\
\hline & Access to GNFI $\rightarrow$ resource management & & + Significant & \\
\hline \multirow{2}{*}{$\mathrm{H} 4$} & $\begin{array}{l}\text { Efficient management of resources } \rightarrow \text { community } \\
\text { development }\end{array}$ & + Significant & + Significant & Accepted \\
\hline & $\begin{array}{l}\text { Efficient management of resources } \rightarrow \text { environmental } \\
\text { activities }\end{array}$ & + Significant & + Significant & \\
\hline \multirow{2}{*}{ H5 } & $\begin{array}{l}\text { GFI } \rightarrow \text { resource management } \rightarrow \text { community } \\
\text { development }\end{array}$ & + Significant & + Significant & Accepted \\
\hline & $\begin{array}{l}\text { GNFI } \rightarrow \text { resource management } \rightarrow \text { community } \\
\text { development }\end{array}$ & + Significant & + Significant & \\
\hline \multirow{2}{*}{ H6 } & $\begin{array}{l}\text { GFI } \rightarrow \text { Resource management } \rightarrow \text { Environmental } \\
\text { activities }\end{array}$ & + Significant & + Significant & $\begin{array}{l}\text { Partially } \\
\text { accepted }\end{array}$ \\
\hline & $\begin{array}{l}\text { GNFI } \rightarrow \text { Resource management } \rightarrow \text { Environmental } \\
\text { activities }\end{array}$ & + Significant & + Significant & \\
\hline
\end{tabular}

\section{Conclusions and discussions}

Drawing on the RBV theory (Barney, 1991), the present study examined the importance of government incentives (financial and nonfinancial) in the attainment of SDGs (community development and environmental practices) with resource management as a mediator in NPOs. Scholars have acknowledged the influence of government subsidies on social welfare and environmental commitment in emerging and advanced countries. However, it is not yet recognized how social organizations manage resources that benefit the maximum number of people. In order to address this research gap, this study planned to advance how government incentives help NPOs to serve communities and protect the environment and how NPOs use the resources. Similarly, the RBV theory has recently debated in social and environmental activities (Ilyas et al., 2020), but rare attention is given to the theory on the relationship between NPOs and SDGs. Individually, the theory (RBV) has not tested in a model to unleash how government financial incentives and nonfinancial incentives configure NPOs toward SDGs. Contributing to the RBV, the study exposed that both financial (tangible) and nonfinancial (intangible) resources are crucial for community development and environmental activities. Hence, the research favours the notion of recent studies (Yusoff et al., 2017) and confirms that resources can be aligned with social and environmental activities and extends the scope of the RBV to NPOs. Additionally, the study endorses that organizations depend on external resources, incentives and support when they intend to practice social and environmental activities. To summarize the theoretical contribution, the research favours as well as extends the scope of the RBV theory to NPOs which contribute to SDGs via public support. 
The results generated from SEM display that government incentives (financial and nonfinancial) do not directly influence community development unless NPOs have efficiently managed the resources. The value of both; government financial and non-financial incentives towards community development are insignificant-displaying that that government incentives do not directly enhance community development. Unlike Degong et al. (2018) the financial incentives provided by domestic government enable SMEs to contribute to community development, our findings displayed insignificant role of government incentives towards community development in NPOs. Our findings show that government financial incentives insignificantly while non-financial incentives significantly affect environmental activities among NPOs. The insignificant results in terms of financial resources might be a high intervention of government, thereby lacking progress of NPOs in environmental initiatives.

Unlike Borumand and Rasti-Barzoki (2019) who claimed that government incentives such as lowering tax, regulation and providing advice have a significant influence on social activities in the organization, the study does not indicate a direct influence of government incentives on community development. It is argued in the present study that NPOs should manage and utilize the resources efficiently in order to provide ultimate paybacks to the societies and poor communities. Our research confirmed our supposition and revealed that NPOs should efficiently manage the incentive received from the government for community development and environmental practices. Because the incentives do not directly influence community development unless NPOs efficiently use and manage the resources. The findings slightly match the notion of Franco and Zapata (2017) who scrutinized that government financial incentives do not benefit in the long run but only benefits the technological capabilities of organizations in the short run. However, the study pageants that resource management partially mediates the path between government incentives and environmental activities. Because the SEM results revealed both significant for the direct influence of government financial and non-financial incentives and indirect through resource management on environmental practices.

The findings favour the argument of Huang et al. (2018) supported, who recommended government policies, incentives and intervention for the adoption of green practices and environmental initiatives. As pointed out by Wang et al. (2020), government incentives and polices encourage organizations to participate in recycling waste resources, so in turn, it gives more benefits. However, in terms of mediation, results partially support Anton et al. (2004) who revealed that regulatory pressure and intervention do not directly affect environmental activities but indirectly through inspiring institutional change and management of environmental trepidations.

Alternatively, resource management is also suggested to be acquired or possessed in order to serve a maximum number of communities. For instance, Ali et al. (2017) scrutinized that institutional governance and management are necessary for up surging sustainable development. Similarly, Long et al. (2016) also discussed that the management of resources such as physical, financial and human is crucial for economic growth and rural development in emerging nations because most organizations (regardless of the nature of activities) face resource constraints in emerging economies (Pakdeechoho \& Sukhotu, 2018). The study discovered that efficient use of resources (financial and nonfinancial) is very crucial in NPOs because they have to serve and facilitate many people. 


\section{Policy implications}

This paper provides important implications for managers, policymakers and practitioners. First, by emphasizing on NPOs and providing them with sufficient resources (financial and nonfinancial), the government can gain its mission of SDGs. Therefore, the government needs to facilitate NPOs and provide them with financial and nonfinancial resources so that they can contribute to SDGs. Second, considering the influence of government financial incentives, it is readily apparent from the findings that NPOs must utilize and manage the resources efficiently in order to benefits the maximum number of people. In other words, the study displays that government financial support does not directly spur SDGs unless NPOs have proper and efficient use of the resources. Third, findings recommend NPOs to use the resource effectively and efficiently if the main emphasis is on social goals and community development. However, the recommendation of efficient use of resource can be weakened if the main goal is protecting environmental and sustainable practices.

Nevertheless, it does not mean that management of resources is not always essential, as discovered from findings that resource management has a significant influence on community development and environmental practices. Alternatively, the study also suggests intellectual and qualified managers for management and use of resources provided by external bodies (e.g. government) as well as internal resources. To summarize, the following significant implications are derived from the study:

- The government needs to provide financial and nonfinancial incentives to NPOs, so they will solely engage in philanthropic activities.

- NPOs need to manage to utilize resources (acquired as well as possessed) efficiently to get maximum benefits.

- NPOs should implement formal procedure and policies for management of government incentives that are used by serving the community and protecting the environment.

\section{Limitations and future research}

The study unleashed the importance of efficient use and management of resources offered by the government in the attainment of SDGs in NPOs and has provided several useful implications for practices. However, like other studies, this study has also some limitations and constraints that are discussed below. The first limitation of this research is the nature of data. We tested the model on cross-sectional evidence that is criticized for common method bias and lack of validity problem. In order to avoid the threat, we suggest an in-depth interview with few NPOs as well as a mixed-method approach to articulate the findings in sound design. The second limitation of this study is the population of the study. For instance, Pakistani NPOs may not adequately represent other NPOs working in Asia and Europe. Therefore, data from other NPOs (Europe and Asian) can give more reliable insights for implications and practice. We also suggest comparative evidence to reveal how NPOs contribute to SDG in emerging and advanced economies when they have adequate access to government incentives. Deliberately, the sample size 263 is also laid in a limitation. The large sample size in the region may provide valid findings. Third, though, the role of government incentives are 
tested to achieve SDGs. However, it is true that NPOs also receive funding and finance from international bodies (banks, individuals and NPOs) and local people for social development. Hence, it will be a fruitful attempt to test how such resources (other than government) are used and managed by NPOs for community development and environment practices.

To conclude the research, we found that government incentives (financial \& nonfinancial) have not a significant direct influence on community development, government financial incentives have an insignificant. In contrast, nonfinancial incentives have a significant direct influence on environmental activities. Resource management fully mediates the paths between government incentives and community development while it partially mediates that links between government incentives and environmental activities, and resource management have a significant favourable influence both community development and environmental activities. The study posits two significant implications; (i) government needs to provide financial and nonfinancial incentives to NPOs, so they will able to help impoverished communities and (ii) NPOs are required to effectively and efficiently manage the acquired resources in order to gain maximum benefits.

\section{Acknowledgements}

This research was supported by the UNKP-20-5-DE-10 New National Excellence Program of the Ministry for Innovation and Technology, and was supported by the Janos Bolyai Research Scholarship of the Hungarian Academy of Sciences.

\section{Author contributions}

MA, MK and DM conceived the study and were responsible for the design and development of the data analysis. MA and MK were responsible for data collection and analysis. JP and DF were responsible for data interpretation. MA, DM wrote the first draft of the article.

\section{Disclosure statement}

The authors declare no conflict of interest.

\section{References}

Aceleanu, M. I., Șerban, A. C., Țîrcă, D. M., \& Badea, L. (2018). The rural sustainable development through renewable energy. The case of Romania. Technological and Economic Development of Economy, 24(4), 1408-1434. https://doi.org/10.3846/20294913.2017.1303650

Adams, R., Kewell, B., \& Parry, G. (2018). Blockchain for good? Digital ledger technology and sustainable development goals. In World sustainability series (pp. 127-140). Springer. https://doi.org/10.1007/978-3-319-67122-2_7

Ali, M. H., Zailani, S., Iranmanesh, M., \& Foroughi, B. (2019). Impacts of environmental factors on waste, energy, and resource management and sustainable performance. Sustainability, 11(8), 2443. https://doi.org/10.3390/su11082443

Ali, S. H., Giurco, D., Arndt, N., Nickless, E., Brown, G., Demetriades, A., Durrheim, R., Enriquez, M. A., Kinnaird, J., Littleboy, A., Meinert, L. D., Oberhänsli, R., Salem, J., Schodde, R., Schneider, G., 
Vidal, O., \& Yakovleva, N. (2017). Mineral supply for sustainable development requires resource governance. Nature, 543(7645), 367-372. https://doi.org/10.1038/nature21359

Alińska, A., Filipiak, B., \& Kosztowniak, A. (2018). The importance of the public sector in sustainable development in Poland. Sustainability, 10(9), 3278. https://doi.org/10.3390/su10093278

Annan-Diab, F., \& Molinari, C. (2017). Interdisciplinarity: Practical approach to advancing education for sustainability and for the Sustainable Development Goals. The International Journal of Management Education, 15(2), 73-83. https://doi.org/10.1016/j.ijme.2017.03.006

Anton, W. R. Q., Deltas, G., \& Khanna, M. (2004). Incentives for environmental self-regulation and implications for environmental performance. Journal of Environmental Economics and Management, 48(1), 632-654. https://doi.org/10.1016/j.jeem.2003.06.003

Anwar, M., Zaman Khan, S., \& Ali Shah, S. Z. (2020). A study of the relationship between innovation and performance among NPOs in Pakistan. Journal of Social Service Research, 46(1), 26-40. https://doi.org/10.1080/01488376.2018.1516265

Apostolopoulos, N., Al-Dajani, H., Holt, D., Jones, P., \& Newbery, R. (Eds.). (2018). How social enterprises can contribute to the Sustainable Development Goals (SDGs) - A conceptual framework. In Entrepreneurship and the Sustainable development goals. Contemporary issues in entrepreneurship research (pp. 33-46). Emerald. https://doi.org/10.1108/S2040-724620188

Arhin, A. (2016). Advancing post-2015 Sustainable development goals in a changing development landscape: Challenges of NGOs in Ghana. Development in Practice, 26(5), 555-568. https://doi.org/10.1080/09614524.2016.1189513

Armstrong, J. S., \& Overton, T. S. (1977). Estimating nonresponse bias in mail surveys. Journal of Marketing Research, 14(3), 396. https://doi.org/10.2307/3150783

Aryal, K., Laudari, H. K., \& Ojha, H. R. (2020). To what extent is Nepal's community forestry contributing to the sustainable development goals? An institutional interaction perspective. International Journal of Sustainable Development and World Ecology, 27(1), 28-39. https://doi.org/10.1080/13504509.2019.1627681

Ayuso, S., \& Navarrete-Báez, F. E. (2018). How does entrepreneurial and international orientation influence SMEs' commitment to sustainable development? Empirical evidence from Spain and Mexico. Corporate Social Responsibility and Environmental Management, 25(1), 80-94. https://doi.org/10.1002/csr.1441

Barney, J. (1991). Firm resources and sustained competitive advantage. Journal of Management, 17(1), 99-120. https://doi.org/10.1177/014920639101700108

Barua, S. (2019). Financing sustainable development goals: A review of challenges and mitigation strategies. Business Strategy \& Development. https://doi.org/10.1002/bsd2.94

Bentler, P. M. (1990). Comparative fit indexes in structural models. Psychological Bulletin, 107(2), 238246. https://doi.org/10.1037/0033-2909.107.2.238

Blum, H., \& Legey, L. F. L. (2012). The challenging economics of energy security: Ensuring energy benefits in support to sustainable development. Energy Economics, 34(6), 1982-1989. https://doi.org/10.1016/j.eneco.2012.08.013

Borumand, A., \& Rasti-Barzoki, M. (2019). A game-theoretic approach to greening, pricing, and advertising policies in a green supply chain. International Journal of Industrial Engineering and Production Research, 30(3), 273-286. https://doi.org/10.22068/ijiepr.30.3.273

Boța-Avram, C., Groşanu, A., Răchişan, P.-R., \& Gavriletea, M. (2018). The bidirectional causality between country-level governance, economic growth and sustainable development: a cross-country data analysis. Sustainability, 10(2), 502. https://doi.org/10.3390/su10020502

Bowen, K. J., Cradock-Henry, N. A., Koch, F., Patterson, J., Hayha, T., Vogt, J., \& Barbi, F. (2017). Implementing the "Sustainable Development Goals": towards addressing three key governance challenges - collective action, trade-offs, and accountability. Current Opinion in Environmental Sustainability, 26-27, 90-96. https://doi.org/10.1016/j.cosust.2017.05.002 
Carius, F., \& Job, H. (2019). Community involvement and tourism revenue sharing as contributing factors to the UN Sustainable Development Goals in Jozani-Chwaka Bay National Park and Biosphere Reserve, Zanzibar. Journal of Sustainable Tourism, 27(6), 826-846. https://doi.org/10.1080/09669582.2018.1560457

Chai, Y., \& Schoon, M. (2016). Institutions and government efficiency: Decentralized irrigation management in China. International Journal of the Commons, 10(1), 21-44. https://doi.org/10.18352/ijc.555

Cheng, H., Hu, X., \& Zhou, R. (2019). How firms select environmental behaviours in China: The framework of environmental motivations and performance. Journal of Cleaner Production, 208, 132-141. https://doi.org/10.1016/j.jclepro.2018.09.096

Christmann, P., \& Taylor, G. (2001). Globalization and the environment: determinants of firm selfregulation in China. Journal of International Business Studies, 32, 439-458. https://doi.org/10.2139/ssrn.277452

Cucchiella, F., D’Adamo, I., Gastaldi, M., \& Miliacca, M. (2018). Efficiency and allocation of emission allowances and energy consumption over more sustainable European economies. Journal of Cleaner Production, 182, 805-817. https://doi.org/10.1016/j.jclepro.2018.02.079

Danso, A., Adomako, S., Amankwah-Amoah, J., Owusu-Agyei, S., \& Konadu, R. (2019). Environmental sustainability orientation, competitive strategy and financial performance. Business Strategy and the Environment, 28(5), 885-895. https://doi.org/10.1002/bse.2291

Degong, M., Ullah, F., Khattak, M. S., \& Anwar, M. (2018). Do international capabilities and resources configure firm's sustainable competitive performance? Research within Pakistani SMEs. Sustainability, 10(11), 4298. https://doi.org/10.3390/su10114298

Deng, W., Yang, T., Tang, L., \& Tang, Y. T. (2018). Barriers and policy recommendations for developing green buildings from local government perspective: a case study of Ningbo China. Intelligent Buildings International, 10(2), 61-77. https://doi.org/10.1080/17508975.2016.1248342

Devalkar, S. K., Sohoni, M. G., \& Arora, P. (2017). Ex-post funding: how should a resource-constrained non-profit organization allocate its funds? Production and Operations Management, 26(6), 10351055. https://doi.org/10.1111/poms. 12633

Doering, O. (1992). Federal policies as incentives or disincentives to ecologically sustainable agricultural systems. Journal of Sustainable Agriculture, 2(3), 21-36. https://doi.org/10.1300/J064v02n03_03

Feliciano, D. (2019). A review on the contribution of crop diversification to Sustainable Development Goal 1 "No poverty" in different world regions. Sustainable Development, 27(4), 795-808. https://doi.org/10.1002/sd.1923

Fornell, C., \& Larcker, D. F. (1981). Evaluating structural equation models with unobservable variables and measurement error. Journal of Marketing Research, 18(1), 39. https://doi.org/10.2307/3151312

Gao, J., Liang, Z., Shang, J., \& Xu, Z. (2019). Remanufacturing with patented technique royalty under asymmetric information and uncertain markets. Technological and Economic Development of Economy, 26(3), 599-620. https://doi.org/10.3846/tede.2019.10287

Guo, Y., Xia, X., Zhang, S., \& Zhang, D. (2018). Environmental regulation, government R \& D funding and green technology innovation: Evidence from China provincial data. Sustainability, 10(4), 940. https://doi.org/10.3390/su10040940

Hafezi, M., \& Zolfagharinia, H. (2018). Green product development and environmental performance: Investigating the role of government regulations. International Journal of Production Economics, 204, 395-410. https://doi.org/10.1016/j.ijpe.2018.08.012

Hair, J., Black, B., Babin, B., \& Anderson, R. (2010). Multivariate data analysis. Prentice-Hall.

Hair, J. F., Babin, B. J., \& Krey, N. (2017). Covariance-based structural equation modeling in the journal of advertising: review and recommendations. Journal of Advertising, 46(1), 163-177.

https://doi.org/10.1080/00913367.2017.1281777 
Hall, J., \& Matos, S. (2010). Incorporating impoverished communities in sustainable supply chains. International Journal of Physical Distribution \& Logistics Management, 40, 124-147. https://doi.org/10.1108/09600031011020368

Harangozo, G., \& Zilahy, G. (2015). Cooperation between business and non-governmental organizations to promote sustainable development. Journal of Cleaner Production, 89, 15-31. https://doi.org/10.1016/j.jclepro.2014.10.092

Hassan, M. M., Lee, K. E., \& Mokhtar, M. (2019). Streamlining non-governmental organizations' programs towards achieving the sustainable development goals: A conceptual framework. Sustainable Development, 27(3), 401-408. https://doi.org/10.1002/sd.1912

Hayes, A. F., \& Scharkow, M. (2013). The relative trustworthiness of inferential tests of the indirect effect in statistical mediation analysis: does method really matter? Psychological Science, 24(10), 1918-1927. https://doi.org/10.1177/0956797613480187

Hooper, D., Coughlan, J., \& Mullen, M. (2007). Structural equation modeling: guidelines for determining model fit. The Electronic Journal of Business Research Methods, 6(1), 53-80.

Hu, L. T., \& Bentler, P. M. (1999). Cutoff criteria for fit indexes in covariance structure analysis: Conventional criteria versus new alternatives. Structural Equation Modeling, 6(1), 1-55. https://doi.org/10.1080/10705519909540118

Huang, S. K., Kuo, L., \& Chou, K. L. (2018). The impacts of government policies on green utilization diffusion and social benefits - A case study of electric motorcycles in Taiwan. Energy Policy, 119, 473-486. https://doi.org/10.1016/j.enpol.2018.04.061

Ilyas, S., Hu, Z., \& Wiwattanakornwong, K. (2020). Unleashing the role of top management and government support in green supply chain management and sustainable development goals. Environmental Science and Pollution Research, 27(8), 8210-8223. https://doi.org/10.1007/s11356-019-07268-3

Imaz, M., \& Sheinbaum, C. (2017). Science and technology in the framework of the sustainable development goals. World Journal of Science, Technology and Sustainable Development, 14, 2-17. https://doi.org/10.1108/WJSTSD-04-2016-0030

Jayaraman, R., La Torre, D., Malik, T., \& Pearson, Y. E. (2015). Optimal work force allocation for energy, economic and environmental sustainability in the united arab emirates: a goal programming approach. In Energy procedia (Vol. 75, pp. 2999-3006). Elsevier Ltd. https://doi.org/10.1016/j.egypro.2015.07.611

Kung, C.-C., Zhang, L., \& Kong, F. (2016). How government subsidy leads to sustainable bioenergy development. Technological Forecasting \& Social Change, 112, 275-278. https://doi.org/10.1016/j.techfore.2016.03.003

Lin, H. (2019). Government-business partnerships for radical eco-innovation. Business \& Society, 58(3), 533-573. https://doi.org/10.1177/0007650316684822

Long, H., Tu, S., Ge, D., Li, T., \& Liu, Y. (2016). The allocation and management of critical resources in rural China under restructuring: Problems and prospects. Journal of Rural Studies, 47, 392-412. https://doi.org/10.1016/j.jrurstud.2016.03.011

MacKenzie, S. B., \& Podsakoff, P. M. (2012). Common method bias in marketing: causes, mechanisms, and procedural remedies. Journal of Retailing, 88(4), 542-555. https://doi.org/10.1016/j.jretai.2012.08.001

Memon, A., Yong An, Z., \& Memon, M. Q. (2020). Does financial availability sustain financial, innovative, and environmental performance? Relation via opportunity recognition. Corporate Social Responsibility and Environmental Management, 27(2), 562-575. https://doi.org/10.1002/csr.1820

Merino-Saum, A., Baldi, M. G., Gunderson, I., \& Oberle, B. (2018). Articulating natural resources and sustainable development goals through green economy indicators: A systematic analysis. Resources, Conservation and Recycling, 139, 90-103. https://doi.org/10.1016/j.resconrec.2018.07.007 
Mia, M. A., Nasrin, S., \& Cheng, Z. (2016). Quality, quantity and financial sustainability of microfinance: Does resource allocation matter? Quality and Quantity, 50(3), 1285-1298. https://doi.org/10.1007/s11135-015-0205-1

Morgan, T., Tokman, M., Richey, R., \& Defee, C. (2018). Resource commitment and sustainability: a reverse logistics performance process model. International Journal of Physical Distribution \& Logistics Management, 48(2), 164-182. https://doi.org/10.1108/IJPDLM-02-2017-0068

Nhamo, G. (2020). Higher education and the energy sustainable development goal: policies and projects from University of South Africa. In G. Nhamo, \& V. Mjimba (Eds.), Sustainable development goals and institutions of higher education (pp. 31-48). Springer. https://doi.org/10.1007/978-3-030-26157-3_3

Nunnally, J. C., \& Bernstein, I. H. (1994). Psychometric theory, Issue 972. McGraw-Hill.

Olson, R. K. (1992). Integrating sustainable agriculture, ecology, and environmental policy. Journal of Sustainable Agriculture, 2(3), 1-7. https://doi.org/10.1300/J064v02n03_01

Omer, M. A. B., \& Noguchi, T. (2020). A conceptual framework for understanding the contribution of building materials in the achievement of Sustainable Development Goals (SDGs). Sustainable Cities and Society, 52, 101869. https://doi.org/10.1016/j.scs.2019.101869

Onnis, L. (2019). Human resource management policy choices, management practices and health workforce sustainability: remote Australian perspectives. Asia Pacific Journal of Human Resources, 57(1), 3-23. https://doi.org/10.1111/1744-7941.12159

Pakdeechoho, N., \& Sukhotu, V. (2018). Sustainable supply chain collaboration: Incentives in emerging economies. Journal of Manufacturing Technology Management, 29(2), 273-294. https://doi.org/10.1108/JMTM-05-2017-0081

Pennerstorfer, A., \& Neumayr, M. (2017). Examining the association of welfare state expenditure, nonprofit regimes and charitable giving. Voluntas, 28(2), 532-555. https://doi.org/10.1007/s11266-016-9739-7

Rasul, G. (2016). Managing the food, water, and energy nexus for achieving the Sustainable Development Goals in South Asia. Environmental Development, 18, 14-25. https://doi.org/10.1016/j.envdev.2015.12.001

Rodríguez Bolívar, M. P., Navarro Galera, A., Alcaide Muñoz, L., \& López Subirés, M. D. (2016). Risk factors and drivers of financial sustainability in local government: An empirical study. Local Government Studies, 42(1), 29-51. https://doi.org/10.1080/03003930.2015.1061506

Rosati, F., \& Faria, L. G. D. (2019). Business contribution to the Sustainable Development Agenda: Organizational factors related to early adoption of SDG reporting. Corporate Social Responsibility and Environmental Management, 26(3), 588-597. https://doi.org/10.1002/csr.1705

Rutkauskas, A. V., Miečinskienè, A., \& Stasytyte, V. (2008). Investment decisions modelling along sustainable development concept on financial markets. Technological and Economic Development of Economy, 14(3), 417-427. https://doi.org/10.3846/1392-8619.2008.14.417-427

Sarikaya, S., \& Buhl, H. U. (2020). The challenge of resource allocation in the nonprofit sector: determining the right amount of fundraising expenses. Journal of Nonprofit and Public Sector Marketing. https://doi.org/10.1080/10495142.2019.1708527

Scheyvens, R., Banks, G., \& Hughes, E. (2016). The private sector and the SDGs: The Need to move beyond 'Business as Usual'. Sustainable Development, 24(6), 371-382. https://doi.org/10.1002/sd.1623

Sheu, J. B., \& Chen, Y. J. (2012). Impact of government financial intervention on competition among green supply chains. International Journal of Production Economics, 138(1), 201-213. https://doi.org/10.1016/j.ijpe.2012.03.024

Song, M., Fisher, R., \& Kwoh, Y. (2019). Technological challenges of green innovation and sustainable resource management with large scale data. Technological Forecasting and Social Change, 144, 361-368. https://doi.org/10.1016/j.techfore.2018.07.055 
Songling, Y., Ishtiaq, M., Anwar, M., \& Ahmed, H. (2018). The role of government support in sustainable competitive position and firm performance. Sustainability, 10(10), 3495. https://doi.org/10.3390/su10103495

Stigson, P., \& Dahlquist, E. (2017). Policies and incentives - natural resources available today and in the future: How to perform change management for achieving a sustainable world. In Natural resources available today and in the future: how to perform change management for achieving a sustainable world (pp. 269-280). Springer International Publishing. https://doi.org/10.1007/978-3-319-54263-8_10

Sueyoshi, T., \& Goto, M. (2019). DEA non-radial approach for resource allocation and energy usage to enhance corporate sustainability in Japanese manufacturing industries. Energies, 12(9), 1785. https://doi.org/10.3390/en12091785

Sueyoshi, T., \& Yuan, Y. (2015). China's regional sustainability and diversified resource allocation: DEA environmental assessment on economic development and air pollution. Energy Economics, 49(49), 239-256. https://doi.org/10.1016/j.eneco.2015.01.024

United Nations. (2003). Studies in methods, Series 61(1), Handbook of national accounting: integrated environmental and economic accounting.

Vasco-Correa, J., Khanal, S., Manandhar, A., \& Shah, A. (2018). Anaerobic digestion for bioenergy production: Global status, environmental and techno-economic implications, and government policies. Bioresource Technology, 247, 1015-1026. https://doi.org/10.1016/j.biortech.2017.09.004

Vladimirova, K., \& Le Blanc, D. (2016). Exploring links between education and sustainable development goals through the lens of UN flagship reports. Sustainable Development, 24(4), 254-271. https://doi.org/10.1002/sd.1626

Wang, Z., Huo, J., \& Duan, Y. (2020). The impact of government incentives and penalties on willingness to recycle plastic waste: An evolutionary game theory perspective. Frontiers of Environmental Science \& Engineering, 14(2), 625-633. https://doi.org/10.1007/s11783-019-1208-2

Wilmshurst, T. D., \& Frost, G. R. (2001). The role of accounting and the accountant in the environmental management system. Business Strategy and the Environment, 10(3), 135-147. https://doi.org/10.1002/bse.283

$\mathrm{Wu}$ J., \& Si, S. (2018). Poverty reduction through entrepreneurship: Incentives, social networks, and sustainability. Asian Business and Management, 17(4), 243-259. https://doi.org/10.1057/s41291-018-0039-5

Yusoff, N. M., Ishak, N. A., Samad, N. H. A., \& Roslan, N. (2017). Financial crisis 2008: Impacts on sustainability of non-profit organizations (NPOs) in Malaysia. Advanced Science Letters, 23(8), 7456-7459. https://doi.org/10.1166/asl.2017.9497

Zaman, K., Abdullah, I., \& Ali, M. (2017). Decomposing the linkages between energy consumption, air pollution, climate change, and natural resource depletion in Pakistan. Environmental Progress \& Sustainable Energy, 36(2), 638-648. https://doi.org/10.1002/ep.12519

Zhai, Z., Shan, M., \& Le, Y. (2020). Investigating the Impact of governmental governance on megaproject performance: evidence from China. Technological and Economic Development of Economy, 26(2), 449-478. https://doi.org/10.3846/tede.2020.11334

Zhang, H., Xiong, L., Li, L., \& Zhang, S. (2018). Political incentives, transformation efficiency and resource-exhausted cities. Journal of Cleaner Production, 196, 1418-1428. https://doi.org/10.1016/j.jclepro.2018.06.093

Zhang, J. J., \& Guan, J. (2018). The time-varying impacts of government incentives on innovation. Technological Forecasting and Social Change, 135, 132-144. https://doi.org/10.1016/j.techfore.2018.04.012

Zhu, H., \& Yoshikawa, T. (2016). Contingent value of director identification: The role of government directors in monitoring and resource provision in an emerging economy. Strategic Management Journal, 37(8), 1787-1807. https://doi.org/10.1002/smj.2408 